\title{
How does Doctors' Information Sharing Behavior Influence Reputation in Online Health Consultation Platform?
}

\author{
Libo Liu \\ University of Melbourne \\ Libo.liu@unimelb.edu.au \\ Chunjun Zhang \\ University of Sydney \\ Czha7787@uni.sydney.edu.au
}

\author{
Xiaofei Zhang \\ Nankai University \\ xiaofeizhang@nankai.edu.cn \\ Zhimin Hua \\ Goldman Sachs \\ zhiminhua@gmail.com
}

\begin{abstract}
The online health consultation platforms provide a unique context for doctors to share health information privately and publicly. However, how doctors' reputation is shaped in the context of online information sharing has been largely neglected in the current literature. This study explores the relationship between information sharing and reputation by distinguishing private and public information sharing behaviours and investigating the contingent roles of doctors' professional and online seniority. Data from a leading online consultation platform in China was obtained to test the research model and associated hypotheses. The results reveal that both private and public sharing can contribute to doctors' online reputation and the effects of the two information sharing behaviours are different about doctors within different professional and online seniority. This study contributes to the literature on health information sharing and online reputation development.
\end{abstract}

\section{Introduction}

Online health platforms provide a new approach for patients and doctors to exchange health and even medical information [1]. As such platforms can overcome the geographic constraints and have a greater scope of health information recipients (e.g., patients and their relatives), as increasing number of doctors are using the online platforms to conduct online health consultations and share knowledge [2]. The previous literature has verified doctors' online information sharing can benefit patients' health management [3] and reduce the health disparities between rural and urban areas $[4,5]$.

Researchers from the fields of psychology, sociology, economics, and political sciences assume that all human actions are ultimately directed toward self-interest. As rational beings, humans look for returns (e.g., prizes, reputation and recognition) by maximizing their benefits and minimizing their costs in the process of information exchange with others [6]. This behavioural perspective has been widely adopted in previous studies [7, 8]. Individuals share and contribute their knowledge to gain informal recognition and establish themselves as experts $[7,8]$. Therefore, it is important to understand how information sharing on online heath consultation (OHC) platforms impacts doctors' reputation. Such insights into doctors' information sharing behaviours will help us to better understand how reputation is influences by these behaviours in OHC context, and also assist doctors to develop better relationship with patients and improve their online services.

Information sharing has been an important area of IS research for nearly two decades [9-13]. Given the increasing proliferation of the Internet, individuals from diverse organizational, national, and cultural backgrounds are able to easily exchange information with others in online community [13-15]. Information sharing on $\mathrm{OHC}$ platforms is different from traditional online communities in the sense that it focuses on communication and consultation with patients, whereas traditional information sharing are shared with unknown online crowds. Trusov, Bucklin and Pauwels [16] reported that user-generated content on social media is seen as a reliable and valuable asset that has significant influence on user decision-making.

Prior research has shown that online reputation can be built through several alternative mechanisms, such as (1) online feedback [17, 18], (2) social interactions [19], (3) past contributions [20], (4) quality of responses posted [20-22] and (5) trust between the online interacting parties [17]. In this study, we focus on two mechanisms including online feedback and past contributions on online reputation building. 
Table 1. Definition of online reputation

\begin{tabular}{|c|c|c|}
\hline Perspectives & Definition of Reputation & Sources \\
\hline \multirow[t]{10}{*}{ Firm } & $\begin{array}{l}\text { An attribute or a set of attributes ascribed to a firm, inferred from the firm's past } \\
\text { actions }\end{array}$ & [23-25] \\
\hline & Public's cumulative judgments of firms over time; a global perception & [26] \\
\hline & Stakeholders' knowledge and emotional reactions - affect, esteem-toward a firm & {$[27,28]$} \\
\hline & Level of awareness that a firm has could develop for itself and for its brands; & [29] \\
\hline & Consumers' expectations and beliefs about a firm's products quality & [30-32] \\
\hline & $\begin{array}{l}\text { Consumers' impressions of a company that is producing and selling a given product } \\
\text { or brand }\end{array}$ & [33] \\
\hline & Perceptions and beliefs about a firm based on previous interactions & {$[34,35]$} \\
\hline & $\begin{array}{l}\text { Organizational reputation can be conceptualized as comprising two dimensions (1) } \\
\text { a perceived quality dimension and (2) a prominence } \\
\text { dimension }\end{array}$ & [36] \\
\hline & $\begin{array}{l}\text { Reputation signal publics about how a firm's products, jobs, strategies, and } \\
\text { prospects compare to those of competing firm. }\end{array}$ & [28] \\
\hline & $\begin{array}{l}\text { Reputation is characterized as an amalgamation of quality and prominence } \\
\text { dimensions. }\end{array}$ & [37] \\
\hline \multirow[t]{5}{*}{ Individual } & An observer's impression of an actor's disposition to behave in a certain manner & [38] \\
\hline & $\begin{array}{l}\text { A prevailing collective agreement about an actor's attributes or achievement based } \\
\text { on what the relevant public "knows" about the actor }\end{array}$ & {$[39,40]$} \\
\hline & A characteristic or an attribute ascribed to an actor based on its past actions & {$[41,42]$} \\
\hline & Estimation of the consistency over time of an attribute of an entity & [43] \\
\hline & Public esteem or high regard & [44] \\
\hline
\end{tabular}

Particularly, we looked at two types of information sharing in OHC platforms: (1) public information sharing and (2) private information sharing. A closer examination of these types of contributions indicates that the influence of these sharing behaviour on doctors' reputation differ. We argue that private information sharing has more influence on online doctors' reputation than public information sharing. Moreover, we are interested in how seniority (i.e., online seniority and offline seniority) moderates the effect of two types of information sharing on online doctors' reputation.

We conducted a field study to compare the effects of information sharing (i.e., public information sharing and private information sharing) on doctors' reputation in which we manipulate information sharing using a natural approach. To elaborate, there are two types of information sharing in $\mathrm{OHC}$ platforms. Public information sharing refers to doctors' information sharing to public in OHC platforms, which means public information sharing is visible to all users. Private information sharing refers to doctors' feedback and recommendations to patients' questions. This information is only visible to patients who raise up the questions. The latter manipulation aligns with $\mathrm{OHC}$ platforms design. This enables us to use behavioural data from Good Doctor Online (https://www.haodf.com) to test our hypotheses in relation to the influence of doctors' information sharing on reputation.

The reminder of this paper is structured as follows. First, we introduce our research model and present hypotheses development. We then describe the methodology of the study and present the results of data analysis. Finally, we conclude with the discussion of the implications, as well as the limitations of our work.

\section{Literature Review}

\subsection{Reputation}

Researchers define reputation as a global impression of a company drawing on institutional theory. Reputation is defined as a output of information exchange and social influence [36, 45, 46]. A review of research on organizational reputation in the management, economics, sociology, and marketing literature reveals that two types of thought are the primarily informants of the construct's definition [47]. Scholars studying reputation from an economic perspective tend to define it as the observers' expectations or estimations of a specific organizational attribute [30, 31]. Companies reduce information asymmetries and market uncertainty, when they make choices that reveal their "true" attributes, which serve as signals that enable buyers to assess relevant 
company attributes [28]. That means reputation reduces stakeholders' concerns about the quality of products in turn to influence companies' economic outcomes [32]. Research indicates that uncertainty can be reduced through the exchange of information in an organizational context. We summarize the definitions of reputation shown in Table 1. mechanism parameters affect market efficiency. Ba and Pavlou [17] examined whether good reputations generate product price premiums. Researchers have examined the impact on online reputation and measure it by the valence of user-generated online reviews that has been shown to be an important performance metric, including books [52], restaurants [53], and video games [54].

Table 2. Antecedents of reputation

\begin{tabular}{|c|c|c|c|c|}
\hline Perspectives & Antecedents of Reputation & Theory & $\begin{array}{l}\text { Research } \\
\text { Context }\end{array}$ & Source \\
\hline \multirow[t]{2}{*}{ Firm } & $\begin{array}{l}\text { Appropriate feedback mechanisms; } \\
\text { Positive and negative feedback ratings; } \\
\text { Trust; } \\
\text { Expensive Product; } \\
\text { Price premiums }\end{array}$ & Game theory & $\begin{array}{l}\text { Electronic } \\
\text { commerce }\end{array}$ & $\begin{array}{l}\text { Ba and Pavlou } \\
\text { [17] }\end{array}$ \\
\hline & Product quality; Ratings & n.a. & $\begin{array}{l}\text { Online review on } \\
\text { hotel }\end{array}$ & Hollenbeck [22] \\
\hline \multirow[t]{7}{*}{ Individual } & Sellers' strategic retaliation behaviour & n.a. & eBay & $\begin{array}{l}\text { Ye, Gao and } \\
\text { Viswanathan } \\
{[18]}\end{array}$ \\
\hline & Ratings of the seller & n.a. & $\begin{array}{l}\text { Online trading } \\
\text { communities }\end{array}$ & $\begin{array}{l}\text { Aperjis and } \\
\text { Johari [48] }\end{array}$ \\
\hline & $\begin{array}{l}\text { Online feedback mechanisms, } \\
\text { social interactions }\end{array}$ & $\begin{array}{l}\text { Game Theory \& } \\
\text { Signaling theory }\end{array}$ & $\begin{array}{l}\text { Online health } \\
\text { communities }\end{array}$ & $\begin{array}{l}\text { Khurana, Qiu } \\
\text { and Kumar [49] }\end{array}$ \\
\hline & $\begin{array}{l}\text { Obligations and controls associated } \\
\text { with a seller's legal status; } \\
\text { seller's local institutional quality }\end{array}$ & $\begin{array}{l}\text { Signalling } \\
\text { theory }\end{array}$ & Online B2B & $\begin{array}{l}\text { Lanzolla and } \\
\text { Frankort [50] }\end{array}$ \\
\hline & $\begin{array}{l}\text { Past contributions } \\
\text { Social voting } \\
\text { Good answers }\end{array}$ & n.a & $\begin{array}{l}\text { Social Q\&A } \\
\text { sites }\end{array}$ & $\begin{array}{l}\text { Paul, Hong and } \\
\text { Chi [20] }\end{array}$ \\
\hline & Answer quality & n.a & $\begin{array}{l}\text { online technical } \\
\text { Q\&A forum }\end{array}$ & $\begin{array}{l}\text { Hart and Sarma } \\
{[21]}\end{array}$ \\
\hline & Social interaction & n.a. & $\begin{array}{l}\text { Online social } \\
\text { networks }\end{array}$ & $\begin{array}{l}\text { Bapna, Gupta, } \\
\text { Rice and } \\
\text { Sundararajan } \\
{[19]}\end{array}$ \\
\hline
\end{tabular}

In the healthcare context, Ivanov and Sharman [37] found that perception of quality has a significantly influence on a hospital's reputation. Perception of quality is influenced by information about organization's underlying capabilities to produce quality goods or services. Based on prior studies of reputation, we define doctor's online reputation as impression of a doctor's online service, which serve as signals that enable patients to assess doctor's relevant service information. It would reduce information asymmetries within patient-doctor interactions.

A large proportion of the existing literature focuses on reputation systems in online communities. Dellarocas [51] studied the reputation mechanism in eBay trading environments to examine how
Havakhor and Sabherwal [55] indicated that reputation signal refers to a signal that indicates the knowledge of a user in a virtual setting. These signals have been primarily used in context of online communities. Individuals look for returns (e.g., reputation and influence) in the process of information exchange with others [56]. The latter perspective has been widely adopted in previous customer information sharing studies [57-60] in which reputation has been recognized as a key driver of content contribution in social media. Individuals share and contribute knowledge to gain informal recognition [7, 8]. We summarized the antecedents of online reputation in Table 2. 
Prior research has shown that online reputation can be built through several alternative mechanisms, such as (1) online feedback $[18,61,62]$, (2) social interactions [63], (3) past contributions [64], (4) quality of responses posted [21, 22, 64] and (5) trust between the online interacting parties [61]. In this study, we focus on two mechanisms including online feedback (i.e., private information sharing) and past contributions (i.e., doctor's public information sharing) on online reputation building.

\section{Research Model and Hypotheses Development}

Rindova, Williamson, Petkova and Sever [36] conceptualized organizational reputation of as consisting of perceived quality and prominence. Perceived quality refers to the degree to which stakeholders evaluate an organization positively on a specific attributes, such as its ability to produce quality products. Perceived quality can be measured by the ratings from stakeholders [37]. Prominence refers to the degree to which an organisation enjoys collective recognition in its industry. Prominence can be measured through the evaluation among peers [37]. We adapt the two-dimensional model of reputation to investigate the antecedents of online reputation in online healthcare platform. We propose that online reputation will be influence by both public information sharing and private sharing. Moreover, service providers' characteristics (i.e., professional seniority and online seniority) will moderate the above relationships. Figure 1 depicts the research model for this study.

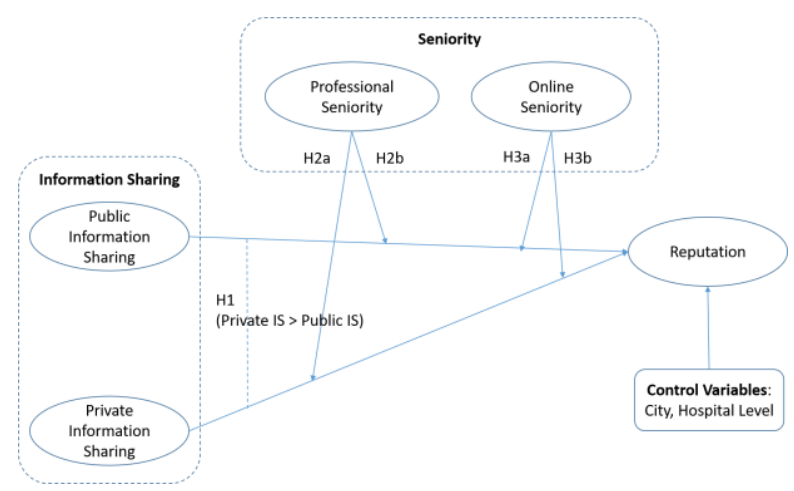

Figure 1. Research model

\subsection{Public information sharing versus private information sharing}

Scant research has examined information sharing behaviour with regard to online health consultation platform. The previous literature focuses on online communities, in which users share ideas [65, 66]. It takes a motivational perspective with an emphasis on perceived benefits and perceived costs to discuss knowledge contributions to online communities. A doctor can share information on OHC platforms. Doctors' information sharing refers to doctors' involvement in OHC platforms in which they share and contribute their knowledge to gain informal recognition and establish reputation (Constant et al, 1994). In this study, we looked at two types of information sharing in an $\mathrm{OCH}$ platform: (1) public information sharing and (2) private information sharing. Public information sharing refers to doctors' information sharing to public in OHC platforms. Private information sharing refers to doctors' feedback and recommendations to patients' questions. This type of information sharing is only available to the patient rather than to public.

In $\mathrm{OHC}$ platforms, when doctors share information (i.e., general information on one disease) this will be displayed to all patients and users. A doctor's performance will be visible or be known only to all users in an $\mathrm{OHC}$ platform. Given that visibility of performance is a determinant of professional knowledge, this information sharing behaviour provides an opportunity for a doctor to manage his or her public image and signal his or her desire for establishing reputation to others. In OHC platforms, doctors can share private feedback and recommendations to patients' questions and requires, which helps build a closer relationship between patients and doctors. The private information sharing provide an opportunity to let patients know their doctors and trust them more. Zhang, Liu and Chen [67] examined observational learning in the social network of friends versus strangers. They found that information cascades are more likely to occur in friend networks than in stranger networks. Thus, we believe that private information sharing carries a stronger signal of doctor's service quality than does public information sharing, thus exerting a stronger impact on doctor's online reputation.

H1: Private information sharing will exert stronger influence on reputation than will public information sharing.

\subsection{OHC platform usage seniority}

Doctors with more experience in OHC platforms usage means they conduct more online consultation for 
patients. A doctor's OHC usage is nurtured as he/she interacts with patients over time. A certain level of shared understanding between doctors and patients allows them to accumulate hands-on experience over time (Zhang et al, 2018). In comparison to doctors with fewer online platform experiences, doctors with longer tenure have a better understanding of whether their information (i.e., sharing views and experiences) are relevant and valuable. These doctors might have already accumulated more feedback and reviews from patients. The positive feedback and reviews will enhance the relationship between information sharing and reputation. Therefore, we have the following hypotheses:

H2a: The positive relationship between public information sharing and reputation is moderated by OHC platforms usage seniority.

$H 2 b$ : The positive relationship between private information sharing and reputation is moderated by OHC platforms usage seniority.

\subsection{Professional seniority}

The professional seniority refers to doctors' professional abilities in hospitals. High professional seniority implies to high practical experience in dealing with patients. When consulting doctors with high professional seniority interact patients, patients usually benefit from the extensive practical experience and perceive these doctors to have a higher reputation [68]. In OHC platforms, doctors' professional seniority is displayed in terms of years of professional, practical experience of working with patients. Patients can find doctors' professional information and personal information on OHC platforms. When consulting with high-seniority doctors who have considerable professional abilities and rich clinical experiences, patients will feel that the doctors have better capability to address their diseases compared to low-seniority doctors. Even if the doctor with low professional seniority shared more information with patients, they are still likely to prefer to be consulted by doctors with high professional seniority. Accordingly, we believe that highly professional seniority will contribute to reduction of doctors' OHC platform sharing behaviour. Therefore, we propose that:

H3a: The positive relationship between public information sharing and reputation is moderated by doctors' professional seniority.

H3b: The positive relationship between private information sharing and reputation is moderated by doctors' professional seniority.

\section{Research Methodology}

\subsection{Data}

We collected data from Good Doctor Online (haodf.com), one of the best online health consultation platforms in China. Based on an Alexa.com report, Good Doctor Online had a traffic rank of 916 in China as of February 2019. The daily browsing visitors is over 3 million, and the daily number of online consultations is round 300,000 . This site had more than 580,000 doctors' information from 9,379 registered hospitals in China as of Dec 2018. Over 200,000 doctors registered in the platform and provide online health consultation service. Each doctor can create a personal profile on his or her home page. On the personal profile, most doctors disclose information,

such as professional through tagging. In addition to these personal statements, doctors may provide vision statements and share their professional knowledge to patients (www.haodf.com).

We sampled real doctors from Good Doctor Online from Beijing City (developed area), Hainan Province (developing area), and Qinghai Province (underdeveloped area). For each doctor, we collected profile information and personal information. To ensure that the sample included only active doctors, we focused on doctors who registered to the platform or who had at least one review from patient. We excluded inactive users as they would have artificially inflated the significance of our results. The resulting sample consisted of 3,554 doctors.

Table 3. Des criptive $s$ tatis tics and correlations

\begin{tabular}{|l|c|c|c|c|c|c|c|c|}
\hline Variables & Mean & S.D. & 1 & 2 & 3 & 4 & 5 & 6 \\
\hline 1. Professional seniority & 2.976 & 0.944 & 1 & & & & & \\
\hline 2. Online seniority & 1512.220 & 1195.020 & 0.342 & 1 & & & & \\
\hline 3. Public information sharing & 6.090 & 29.334 & 0.127 & 0.217 & 1 & & & \\
\hline 4. Private information sharing & 132.740 & 389.359 & 0.035 & 0.209 & 0.294 & 1 & & \\
\hline 4. Reputation & 3.678 & 0.283 & 0.210 & 0.338 & 0.241 & 0.494 & & \\
\hline 5. Hospital level & 8.708 & 1.167 & 0.125 & 0.084 & 0.018 & 0.048 & 1 & \\
\hline 6. City & 5.958 & 4.152 & 0.015 & 0.225 & 0.072 & 0.102 & 0.243 & 1 \\
\hline
\end{tabular}




\subsection{Operationalization of constructs}

There are four hierarchical clinical titles for doctors (i.e., resident doctor, attending doctor, associate chief doctor, and chief doctor) in the Chinese health care system [68]. For professional seniority, we used 1 to represent clinician, 2 to represent attending doctor, 3 for associate senior doctor, and 4 for senior doctor. Online seniority is operationalized as the total number of days a doctor uses the platform. Public information sharing is operationalized as the total number of articles a doctor share to public in the platform. Private information sharing is operationalized as the total number of feedback a doctor provide to patient in the platform. Reputation is operationalized as the rating of the doctor received from the platform. There are ten hierarchical level for hospital in the Chinese health care system. Hospital level is using to indicate hospital level. We use 10 to represent top level, and 1 to represent lowest level of hospital. Table 3 presents the summary of statistics and correlations of the variables.

\section{Data Analysis and Results}

To test our research model, we ran a linear regression using SPSS. Table 4 presents the results of the studied models. The first model tests the effects of control variables including city and hospital level. The second model tests the effects of independent variables with control variables. The third model tests the effects of independent variable with moderators. The fourth model tests the moderating effect of online seniority. The fifth model tests the moderating effect of professional seniority.

In model 1, the regression results suggest that both city and hospital level have significant effects on doctors' reputation $(\beta=0.448, p<0.01 ; \beta=0.217, p<$ 0.01 ). Model 1 explains $30.0 \%$ of the variation in doctors' reputation. Model 2 confirms the positive and statistically significant effect of doctors' professional seniority on doctors' reputation $(\beta=0.187, \mathrm{p}<0.01)$ and the positive and statistically significant effect of doctors' online seniority on doctors' reputation $(\beta=$ $0.176, p<0.01)$. Model 2 explains the variation of doctors' reputation by $32.9 \%$.

Table 4. Analys is results of the main effects

\begin{tabular}{|c|c|c|c|c|c|}
\hline Variables & Model 1 & Model 2 & Model 3 & Model 4 & Model 5 \\
\hline \multicolumn{6}{|l|}{ Moderators } \\
\hline Professional Seniority & & $\begin{array}{l}0.187 * * * \\
(0.005)\end{array}$ & $\begin{array}{c}0.164 * * * \\
(0.004)\end{array}$ & & $\begin{array}{l}0252 * * * \\
(0.005)\end{array}$ \\
\hline Online Seniority & & $\begin{array}{c}0.176^{* * *} \\
(0.000005)\end{array}$ & $\begin{array}{l}0.084 * * * \\
(0.000004)\end{array}$ & $\begin{array}{l}0.201 * * * \\
(0.000005)\end{array}$ & \\
\hline \multicolumn{6}{|l|}{ Independent Variables } \\
\hline Public Information sharing & & & $\begin{array}{l}0.041 * * * \\
(0.00015)\end{array}$ & $\begin{array}{c}0.197 * * * \\
(0.001)\end{array}$ & $\begin{array}{l}-0.068 \\
(0.001)\end{array}$ \\
\hline Private Information sharing & & & $\begin{array}{l}0.449 * * * \\
(0.00001)\end{array}$ & $\begin{array}{l}0.306 * * * \\
(0.000024)\end{array}$ & $\begin{array}{l}0.625 * * * \\
(0.000042)\end{array}$ \\
\hline \multicolumn{6}{|l|}{ Interactions } \\
\hline $\begin{array}{l}\text { Professional Seniority } * \\
\text { Public Information sharing }\end{array}$ & & & & & $\begin{array}{c}0.250 * * \\
(0.000350)\end{array}$ \\
\hline $\begin{array}{l}\text { Professional Seniority }{ }^{*} \\
\text { Private Information sharing }\end{array}$ & & & & & $\begin{array}{l}0.136^{* * * *} \\
(0.000013)\end{array}$ \\
\hline $\begin{array}{l}\text { Online Seniority * } \\
\text { Public Information sharing }\end{array}$ & & & & $\begin{array}{c}-0.169 \\
(2.1558 \mathrm{E}-7) \\
\end{array}$ & \\
\hline $\begin{array}{l}\text { Online Seniority * } \\
\text { Private Information sharing }\end{array}$ & & & & $\begin{array}{c}0.201 * * * \\
(1.0789 \mathrm{E}-8)\end{array}$ & \\
\hline \multicolumn{6}{|l|}{ Control Variables } \\
\hline City & $\begin{array}{c}0.448^{* * * *} \\
(0.001)\end{array}$ & $\begin{array}{c}0.409 * * * \\
(0.001)\end{array}$ & $\begin{array}{c}0.401 * * * \\
(0.004)\end{array}$ & $\begin{array}{c}0.406 * * * \\
(0.001)\end{array}$ & $\begin{array}{c}0.381 * * * \\
(0.001)\end{array}$ \\
\hline Hospital Level & $\begin{array}{c}0.217 * * * \\
(0.003) \\
\end{array}$ & $\begin{array}{c}0.070 * * * \\
(0.004)\end{array}$ & $\begin{array}{c}0.068 * * * \\
(0.003)\end{array}$ & $\begin{array}{c}0.073 * * * \\
(0.004) \\
\end{array}$ & $\begin{array}{c}0.109 * * * \\
(0.003)\end{array}$ \\
\hline Observations & 3,554 & 3,554 & 3,554 & 3,554 & 3,554 \\
\hline Adjust R-square & 0.300 & 0.329 & 0.531 & 0.333 & 0.537 \\
\hline
\end{tabular}


Model 3 confirms the positive and statistically significant effect of two moderators public information sharing and private information sharing $(\beta=0.041, \mathrm{p}<$ $0.01 ; \beta=0.449, \mathrm{p}<0.01$ ). A comparison of the two $\beta$ coefficients reveals that private information sharing is the more influential predictor than public information sharing (Wald $t=6.85, d f=1, p<0.0001$ ), suggesting that the greater the number of private information sharing provided, the more reputation the doctors will received. Thus, $\mathrm{H} 1$ is supported.

Model 4 test the moderation effect of online seniority. Model 4 confirms the positive significant moderating effect of online seniority on the relationship between private information sharing on doctors' reputation $(\beta=0.201, \mathrm{p}<0.001)$. Therefore, $\mathrm{H} 2 \mathrm{~b}$ is supported. However, online seniority doesn't show the moderating effect on the relationship between public information sharing on doctors' reputation. $\mathrm{H} 2 \mathrm{~b}$ is not supported. Model 4 explains the variation of doctors' reputation by $33.3 \%$.

Model 5 test the moderation effect of professional seniority. It confirms significant moderating effect of professional seniority on the relationship between public information sharing on doctors' reputation $(\beta=$ $0.250, p<0.05$ ). Therefore, H3a is supported. The result indicated the positive significant moderating effect of professional seniority on the relationship between private information sharing on doctors' reputation $(\beta=0.136, p<0.01)$. Thus, $\mathrm{H} 3 \mathrm{~b}$ is supported. Model 5 explains the variation of doctors' reputation by $53.7 \%$. The results are summarized in Table 2.

\section{Conclusion and Discussion}

In this study, we looked at two types of information sharing in OHC platforms: (1) public information sharing and (2) private information sharing. We argue that private information sharing has more influence on online doctors' reputation than public information sharing. Moreover, we are interested in how seniority (i.e., online seniority and offline seniority) moderate the effect of two types of information sharing on online doctors' reputation.

We conducted a field study to compare the effects of information sharing (i.e., public information sharing and private information sharing) on doctors' reputation. The results show that private information sharing exert stronger influence on reputation than will private information sharing. Online seniority positively moderates the relationship between private information sharing and reputation. Professional seniority positively moderated the relationship between information sharing (i.e., private information sharing and public information sharing) and reputation.

\subsection{Theoretical Implications}

This study contributes to the current literature in several aspects. First, this study is one of the first to explore how doctors generate reputation from both public and private information sharing behaviour. Second, this work enriches the literature of information sharing by proposing two different sharing mechanisms of doctors in online platforms and further explore the relative effects of the two different sharing behaviour on reputation development. Third, by precisely exploring the contingent role of professional and online seniority, this study also gains the knowledge of doctors' online sharing behaviours and the corresponding outcomes. Practically, this study can provide insight for doctors on how to manipulate their online reputations from different information sharing behaviour and how their sharing behaviours contribute reputation about different doctor groups (based on professional seniority and online seniority).

\subsection{Practical Implications}

This study also provides practical implications for online physicians and platforms. We found that physicians' generalized and customized knowledge sharing can increase their online reputation. Based on this finding, physicians are first suggested to share more customized knowledge to help patients to increase the number of patient ratings. Physicians should be more active in the online platforms to recruit more patients, reply their inquires more quickly, and provide useful information. Second, physicians can also share more generalized information to increase their reputation by publishing more patient education articles and sending more health notices. Platforms can also encourage patients to share more information to patients. They can provide incentives to increase physicians' motivation to knowledge-sharing.

\subsection{Limitations and Future Research}

Our study is not without limitations. First, the generalizability of our results may be limited because we examined only one OHC platform in China. Future studies should examine whether $\mathrm{OHC}$ plaforms from other countries exhibit similar dynamics and compare the impact of information sharing across different $\mathrm{OHC}$ platforms. Second, our study measured private information sharing behaviour by using aggregated data. Future study could use social network analysis to explore how network structure (e.g., strong tie and 
weak tie between doctors and patients) influence doctors' reputation. Finally, as the influence of private information sharing on online reputation shows more effects comparing with public information sharing, future study could compare difference in moderating effects of professional seniority and online seniority on those relationships.

\section{Acknowledgement}

The work described in this paper was partially supported by a grant from the National Nature Science Foundation of China (Project No. 71701169).

\section{References}

[1]. Guo, S., Guo, X., Fang, Y., and Vogel, D. How doctors gain social and economic returns in online health-care communities: a professional capital perspective. Journal of Management Information Systems, 34, 2 (2017), pp. 487-519.

[2]. Wu, Y., and Po, H. China's changing pharmaceutical E-commerce market. Beijing, China: Deloitte China, 2016.

[3]. Barrett, M., Oborn, E., and Orlikowski, W. Creating value in online communities: The sociomaterial configuring of strategy, platform, and stakeholder engagement. Information Systems Research, 27, 4 (2016), pp. 704-723.

[4]. Mein Goh, J., Gao, G., and Agarwal, R. The creation of social value: Can an online health community reduce rural-urban health disparities? MIS Quarterly, 40, 1 (2016), pp. 247-263.

[5]. Cao, X., and Wang, D. The role of online communities in reducing urban-rural health disparities in China. Journal of the Association for Information Science and Technology, 69, 7 (2018), pp. 890-899.

[6]. Lakhani, K.R., and Von Hippel, E. How open source software works:"free" user-to-user assistance. Produktentwicklung mit virtuellen Communities: Springer, 2004, pp. 303-339.

[7]. Constant, D., Kiesler, S., and Sproull, L. What's mine is ours, or is it? A study of attitudes about information sharing. Information Systems Research, 5, 4 (1994), pp. 400-421.

[8]. Constant, D., Sproull, L., and Kiesler, S. The kindness of strangers: The usefulness of electronic weak ties for technical advice. Organization science, 7 , 2 (1996), pp. 119-135.

[9]. Alavi, M., and Leidner, D.E. Review: Knowledge management and knowledge management systems: Conceptual foundations and research issues. MIS quarterly, 25, 1 (2001), pp. 107-136.

[10]. Jarvenpaa, S.L., and Staples, D.S. The use of collaborative electronic media for information sharing: an exploratory study of determinants. The Journal of Strategic Information Systems, 9, 2-3 (2000), pp. 129154.

[11]. Ma, M., and Agarwal, R. Through a glass darkly: Information technology design, identity verification, and knowledge contribution in online communities. Information systems research, 18, 1 (2007), pp. 42-67. [12]. Sambamurthy, V., and Subramani, M. Special issue on information technologies and knowledge management. MIS quarterly, 29, 2 (2005), pp. 193-195. [13]. Nunamaker Jr, J.F., and Briggs, R.O. Toward a broader vision for information systems. ACM Transactions on Management Information Systems (TMIS), 2, 4 (2011), pp. 20.

[14]. Sen, S., Raghu, T., and Vinze, A. Demand information sharing in heterogeneous IT services environments. Journal of Management Information Systems, 26, 4 (2010), pp. 287-316.

[15]. Wenger, E. Communities of practice: Learning as a social system. Systems thinker, 9, 5 (1998), pp. 2-3. [16]. Trusov, M., Bucklin, R.E., and Pauwels, K. Effects of word-of-mouth versus traditional marketing: Findings from an internet social networking site. Journal of marketing, 73, 5 (2009), pp. 90-102.

[17]. Ba, S., and Pavlou, P.A. Evidence of the effect of trust building technology in electronic markets: Price premiums and buyer behavior. MIS Quarterly (2002), pp. 243-268.

[18]. Ye, S., Gao, G., and Viswanathan, S. Strategic Behavior in Online Reputation Systems. MIS Quarterly, 38, 4 (2014), pp. 1033-1056.

[19]. Bapna, R., Gupta, A., Rice, S., and Sundararajan, A. Trust and the Strength of Ties in Online Social Networks: An Exploratory Field Experiment. MIS Q.uarterly, 41, 1 (2017), pp. 115-130.

[20]. Paul, S.A., Hong, L., and Chi, E.H. Who is authoritative? understanding reputation mechanisms in quora. arXiv preprint arXiv:. (2012).

[21]. Hart, K., and Sarma, A. Perceptions of answer quality in an online technical question and answer forum. Proceedings of the 7th International Workshop on Cooperative and Human Aspects of Software Engineering, 2014, pp. 103-106.

[22]. Hollenbeck, B. Online reputation mechanisms and the decreasing value of chain affiliation. Journal of Marketing Research, 55, 5 (2018), pp. 636-654.

[23]. Weigelt, K., and Camerer, C. Reputation and corporate strategy: A review of recent theory and applications. Strategic Management Journal, 9, 5 (1988), pp. 443-454.

[24]. Hayward, M.L., and Boeker, W. Power and conflicts of interest in professional firms: Evidence from investment banking. Administrative Science Quarterly (1998), pp. 1-22. 
[25]. Stuart, T.E. Interorganizational alliances and the performance of firms: a study of growth and innovation rates in a high - technology industry. Strategic Management Journal, 21, 8 (2000), pp. 791 811.

[26]. Roberts, P.W., and Dowling, G.R. Corporate reputation and sustained superior financial performance. Strategic Management Journal, 23, 12 (2002), pp. 1077-1093.

[27]. Deephouse, D.L. Media reputation as a strategic resource: An integration of mass communication and resource-based theories. Journal of Management, 26, 6 (2000), pp. 1091-1112.

[28]. Fombrun, C., and Shanley, M. What's in a name? Reputation building and corporate strategy. Academy of Management Journal, 33, 2 (1990), pp. 233-258.

[29]. Shamsie, J. The context of dominance: an industry - driven framework for exploiting reputation. Strategic Management Journal, 24, 3 (2003), pp. 199215.

[30]. Allen, F. Reputation and product quality. The RAND Journal of Economics (1984), pp. 311-327.

[31]. Shapiro, C. Consumer information, product quality, and seller reputation. The Bell Journal of Economics (1982), pp. 20-35.

[32]. Shapiro, C. Premiums for high quality products as returns to reputations. The Quarterly Journal of Economics, 98, 4 (1983), pp. 659-679.

[33]. Goldberg, M.E., and Hartwick, J. The effects of advertiser reputation and extremity of advertising claim on advertising effectiveness. Journal of Consumer Research, 17, 2 (1990), pp. 172-179.

[34]. Campbell, M.C. Perceptions of price unfairness: antecedents and consequences. Journal of Marketing Research, 36, 2 (1999), pp. 187-199.

[35]. Prabhu, J., and Stewart, D.W. Signaling strategies in competitive interaction: Building reputations and hiding the truth. Journal of Marketing Research, 38, 1 (2001), pp. 62-72.

[36]. Rindova, V.P., Williamson, I.O., Petkova, A.P., and Sever, J.M. Being good or being known: An empirical examination of the dimensions, antecedents, and consequences of organizational reputation. Academy of Management Journal, 48, 6 (2005), pp. 1033-1049.

[37]. Ivanov, A., and Sharman, R. Impact of usergenerated internet content on hospital reputational dynamics. Journal of Management Information Systems, 35, 4 (2018), pp. 1277-1300.

[38]. Clark, B.H., and Montgomery, D.B. Deterrence, reputations, and competitive cognition. Management Science, 44, 1 (1998), pp. 62-82.

[39]. Lang, G.E., and Lang, K. Recognition and renown: The survival of artistic reputation. American Journal of Sociology, 94, 1 (1988), pp. 79-109.
[40]. Camic, C. Reputation and predecessor selection: Parsons and the institutionalists. American Sociological Review (1992), pp. 421-445.

[41]. Kollock, P. The emergence of exchange structures: An experimental study of uncertainty, commitment, and trust. American Journal of Sociology, 100, 2 (1994), pp. 313-345.

[42]. Raub, W., and Weesie, J. Reputation and efficiency in social interactions: An example of network effects. American Journal of Sociology, 96, 3 (1990), pp. 626-654.

[43]. Herbig, P., and Milewicz, J. The relationship of reputation and credibility to brand success. Journal of Consumer Marketing, 12, 4 (1995), pp. 5-11.

[44]. Weiss, A.M., Anderson, E., and MacInnis, D. The impact of reputation on the choice of sales organization. Journal of Marketing, 63, 4 (1999).

[45]. Brown, R. Build your reputation: Grow your personal brand for career and business success. John Wiley \& Sons, 2016.

[46]. Silver, I.M., and Shaw, A. Pint-sized public relations: The development of reputation management. Trends in Cognitive Sciences, 22, 4 (2018), pp. 277279.

[47]. Walker, K. A systematic review of the corporate reputation literature: Definition, measurement, and theory. Corporate Reputation Review, 12, 4 (2010), pp. 357-387.

[48]. Aperjis, C., and Johari, R. Optimal windows for aggregating ratings in electronic marketplaces. Management Science, 56, 5 (2010), pp. 864-880.

[49]. Khurana, S., Qiu, L., and Kumar, S. When a doctor knows, it shows: an empirical analysis of doctors' responses in a Q\&A forum of an online healthcare portal. Information Systems Research, 30, 3 (2019), pp. 872-891.

[50]. Lanzolla, G., and Frankort, H.T. The online shadow of offline signals: Which sellers get contacted in online B2B marketplaces? Academy of Management Journal, 59, 1 (2016), pp. 207-231.

[51]. Dellarocas, C. The digitization of word of mouth: Promise and challenges of online feedback mechanisms. Management Science, 49, 10 (2003), pp. 1407-1424.

[52]. Chevalier, J.A., and Mayzlin, D. The effect of word of mouth on sales: Online book reviews. Journal of Marketing Research, 43, 3 (2006), pp. 345-354.

[53]. Anderson, M., and Magruder, J. Learning from the crowd: Regression discontinuity estimates of the effects of an online review database. The Economic Journal, 122, 563 (2012), pp. 957-989.

[54]. Zhu, F., and Zhang, X. Impact of online consumer reviews on sales: The moderating role of product and consumer characteristics. Journal of Marketing, 74, 2 (2010), pp. 133-148. 
[55]. Havakhor, T., and Sabherwal, R. Team processes in virtual knowledge teams: The effects of reputation signals and network density. Journal of Management Information Systems, 35, 1 (2018), pp. 266-318.

[56]. Lakhani, K.R., and Von Hippel, E. How open source software works:"free" user-to-user assistance. Research policy, 32, 6 (2003), pp. 923-943.

[57]. Cheung, C.M., and Lee, M.K. What drives consumers to spread electronic word of mouth in online consumer-opinion platforms. Decision Support Systems, 53, 1 (2012), pp. 218-225.

[58]. Hennig Thurau, T., Gwinner, K.P., Walsh, G., and Gremler, D.D. Electronic word of mouth via consumer opinion platforms: What motivates consumers to articulate themselves on the Internet? Journal of Interactive Marketing, 18, 1 (2004), pp. 3852.

[59]. Liu, D., Ray, G., and Whinston, A.B. The interaction between knowledge codification and knowledge-sharing networks. Information Systems Research, 21, 4 (2010), pp. 892-906.

[60]. Sun, T., Youn, S., Wu, G., and Kuntaraporn, M. Online Word - of - Mouth (or Mouse): An Exploration of Its Antecedents and Consequences. Journal of Computer - Mediated Communication, 11, 4 (2006), pp. 1104-1127.

[61]. Ba, S., and Pavlou, P.A. Evidence of the effect of trust building technology in electronic markets: Price premiums and buyer behavior. MIS quarterly, 26, 3 (2002), pp. 243-268.

[62]. Rice, S.C. Reputation and uncertainty in online markets: an experimental study. Information systems research, 23, 2 (2012), pp. 436-452.

[63]. Bapna, R., Gupta, A., Rice, S., and Sundararajan, A. Trust and the Strength of Ties in Online Social Networks: An Exploratory Field Experiment. MIS quarterly, 41, 1 (2017), pp. 115-130.

[64]. Paul, S.A., Hong, L., and Chi, E.H. Who is authoritative? understanding reputation mechanisms in quora. arXiv preprint arXiv: (2012).

[65]. Cheema, A., and Kaikati, A.M. The effect of need for uniqueness on word of mouth. Journal of Marketing research, 47, 3 (2010), pp. 553-563.

[66]. Faraj, S., Kudaravalli, S., and Wasko, M. Leading collaboration in online communities. MIS quarterly, 39, 2 (2015).

[67]. Zhang, J., Liu, Y., and Chen, Y. Social learning in networks of friends versus strangers. Marketing Science, 34, 4 (2015), pp. 573-589.

[68]. Zhang, X., Guo, X., Lai, K.-h., and Yi, W. How does online interactional unfairness matter for patientdoctor relationship quality in online health consultation? The contingencies of professional seniority and disease severity. European Journal of Information Systems (2018), pp. 1-19. 